\title{
Impact of Propensity to Trust on Academic Success of Student- Athletes: Implications for Student-Athlete Academic Support in Higher Education
}

\author{
Dr. Trevor Wilson ${ }^{1}$, Pamela R. Hallam ${ }^{2}$, Donald Baum ${ }^{3}$, Michael Owens ${ }^{4}$ \\ ${ }^{1}$ Associate Dean of Students. Brigham Young University, USA \\ ${ }^{2}$ Associate Professor and Chair of the Educational Leadership and Foundations Department at Brigham Young \\ University, USA \\ ${ }^{3}$ Assistant Professor of Education Policy at Brigham Young University, USA \\ ${ }^{4}$ Associate professor in the McKay School of Education's Educational Leadership and Foundations Department \\ at Brigham Young University, USA
}

*Corresponding Author: Dr. Trevor Wilson, Associate Dean of Students. Brigham Young University, USA

\begin{abstract}
Student-athletes enter higher education in the United States with diverse backgrounds, including their levels of academic preparation. Some are underprepared for these institutions' academic rigor, social pressures, and ethical expectations. Athletic coaches recruit skilled, competitive athletes, while other athletic officials provide for their academic support and overall well-being. Trust is critical in helping these students balance the stresses of athletic participation and academic demands. This study investigated the relationship between student-athletes' propensity to trust and their academic performance at a large private research and National Collegiate Athletic Association Division I university. Statistical analyses that identified differences in propensity to trust (PTT) by demographic and educational characteristics and team affiliation found that PPT is positively associated with student academic performance. Implications suggest that PPT is a relevant consideration in properly supporting student-athletes, and that a PPT measure may be useful when recruiting student-athletes as well.
\end{abstract}

Key words: athlete, propensity to trust, higher education

\section{INTRODUCTION}

The National Collegiate Athletic Association (NCAA) was founded in 1906to protect young people from dangerous and exploitive practices (NCAA.org, n.d.), in response to a movement emphasizing the dangers of football and calling for regulation to safeguard college participants. The simple regulations protecting students who are athletes (student-athletes) enforced by the NCAA at its inception have evolved into a complex set of rules, regulations, and eligibility standards. Regulations now fully established include the requirement that institutions engaging in NCAA Division I college sports monitor the academic progress and success of their student-athletes.

Despite the NCAA emphasis on student-athletes, ${ }^{*}$ some athletes who are recruited for outstanding performance in their sport enter a college lacking the proper academic habits or preparation to succeed as students. To mitigate this issue, the NCAA encourages institutions to implement support systems. NCAA By-Law 16.3.1.1 state,

Member institutions shall make general academic counseling and tutoring services available to all student-athletes. . . .In addition, an institution, conference, or the NCAA may finance other academic support, career counseling, or personal development services that support the success of student-athletes. (NCAA, 2014, p. 26)

\footnotetext{
* The NCAA uses the construction student-athlete in order to emphasize that the individua is both a student and an athlete.
} 
Athletic administrators are charged to financially support these services. Athletic coaches are encouraged to mandate that their student-athletes participate in academic support structures, and academic support staff are charged with providing the needed assistance.

The purpose of this study was to examine the impact propensity to trust their academic support staff may have on NCAA Division I student-athletes' academic success. Academic advisors, learning specialists, and other academic support staff are charged with providing student-athletes with adequate academic support as well as helping them maintain academic eligibility by progressing toward graduation. Student-athletes who have a low propensity to trust are more susceptible to heightened stress, fear, and anxiety. As a result they may be more likely to face consequences such as academic dysfunction and loss of eligibility. If academic support staff can identify student-athletes' propensity to trust, they may be able to identify strategies and gain insight that will help them acquire student-athletes' trust so they can provide more effective support. As student-athletes follow the advice of their academic support staff, they will be more likely to improve their academic performance and alleviate stress. In addition, coaches and personnel who identify prospective student-athletes to recruit may be able to consider propensity to trust as a recruiting criterion.

\section{REVIEW OF RESEARCH ON TRUST}

\subsection{Development of Trust Research}

Recent trust research in the social sciences gained early impetus with Rosenberg's 1957 concept of "faith in people" (Rosenberg, Suchman, \&Goldsen, 1957) and Deutsch's research. These authors defined trust as "the individual's degree of confidence in the trustworthiness, honesty, goodness, generosity, and brotherliness of the mass of men" (Rosenberg et al., 1957, p. 26) with "motivational consequences" (Deutsch, 1958, p. 266). Building on Rosenberg's characterization of trust as an interpersonal factor, Rotter (1967) developed an interpersonal trust scale that was widely used for several decades. Rotter defined interpersonal trust as "an expectancy held by an individual or a group that the word, promise, verbal or written statement of another individual or group can be relied upon" (1967, p. 651).

In 1993 Sitkin and Roth concluded that "nearly all research has at least implicitly accepted a definition of trust as a belief, attitude, or expectation concerning the likelihood that the actions or outcomes of another individual, group or organization will be acceptable" (p. 368). These researchers specified that trust is "belief in a person's competence to perform a specific task under specific circumstances" (p. 373).

One of the most frequently cited definitions of trust during recent decades has been Mayer, Davis, and Schoorman's (1995) extension:

The willingness of a party to be vulnerable to the actions of another party based on the expectation that the other will perform a particular action important to the trustor, irrespective of the ability to monitor or control that other party. (p. 712)

This definition has been a prominent basis for additional research (Hoy \&Tschannen-Moran, 1999; Mishra, 1996; Rousseau, Sitkin, Burt, \& Camerer, 1998; Serva, Fuller, \& Mayer, 2005).

One notable variation from Mayer et al.'s definition (1995) was offered by Costa, Roe, and Taillieu (2001), similar to Tschannen-Moran and Hoy (2000),conceptualizing trust as a multifaceted variable with three distinct but interrelated dimensions: propensity to trust, perceived trustworthiness, and cooperative and monitoring behaviors. In this definition propensity to trust was a dispositional variable, a variance furthering the need to maintain a distinction between propensity to trust (i.e., indicating general willingness to trust) and actual trust (i.e., engaging in trusting behaviors; Mayer et al., 1995).

\subsection{Specification of Propensity to Trust}

While the general construct of propensity to trust has been included in trust research since

Rosenberg's (1957) "faith in people" principle, it has become more central to the field during the last two decades. Research has established that propensity to trust moderates the relationship between the antecedent to trust and the exercise of trust in the trustee (Burke, Sims, Lazzara, \& Salas, 2007). Mayer et al. (1995) looked at ability, benevolence, and integrity-the "factors of perceived trustworthiness"- as the three main categorical antecedents to trust, listing "trustor's propensity" as "a stable within-party factor that will affect the likelihood the party will trust" (p. 715). Their model 
did not consider ability, benevolence, and integrity as antecedents to propensity to trust, but listed them sequentially prior to it, indicating that propensity to trust influences the relationship between the factors of perceived trustworthiness and trust. Thus propensity to trust moderates the three antecedents to trust. In discussing previous research regarding propensity to trust, the authors have stated that "propensity should contribute to the explanation of variance in trust if used as a part of a more complete set of variables" (Mayer et al., 1995, p. 716).

This study has defined propensity to trust using the widely cited work by Mayer et al. (1995): "a general willingness to trust others" (p. 715). Other researchers have used similar but varied terminology such as a "capacity to trust" (Hardin, 1993, p. 513). Research has suggested that the predisposition to trust or distrust others tends to be correlated with other dispositional orientations, including people's "beliefs about human nature" (Kramer, 1999, p. 575). The term "disposition to trust" has been used by other authors (Gill, Boies, Finegan, \& McNally, 2005; McKnight, Cummings, \&Chervany, 1998; Tschannen-Moran \& Hoy, 2000).

Burke et al. (2007) also used predisposition, but they defined propensity to trust as "the general willingness to place faith in others' reciprocity and good intentions" (p. 619) and "a general tendency to make positive attributions about others' intentions" (p. 609).Like Hardin (1993), Burke et al. (2007) posited that "an individual's propensity to trust is developed from previous learned experiences"(p. 619).

Other terms and definitions highlight aspects of the construct of propensity to trust. Motivation to trust was explained by Williams (2001) as "the desire to view another person as trustworthy enough to be relied on" (p. 387). Gill et al. (2005) used the phrase "intention to trust" as a construct strongly related to "propensity to trust," but not identical: distinguished in operational definitions and measured by separate scales. Each definition has contributed differently to the establishment of trust, according to individual situations. Gill et al. (2005) distinguished "intention to trust by the personal disposition of the trustor" (p. 289); Mayer et al. (1995) considered propensity to trust to be influenced more specifically by the trustor's ability, benevolence, and integrity. Burke et al. (2007) explained that "propensity to trust impacts the information that is salient and how the information is processed when deciding to trust" (p. 619). High propensity to trust tends to strengthen ones' belief in the trustworthiness of others.

\subsection{Trust and Propensity to Trust in the Context of Student-Athletes}

Little research has been done on trust applied to student-athletes. Further, little uviversity-level foundational literature can be found on propensity to trust (Brown, Hallam, Hite \& Hite, 2016). This study was undertaken to help fill gaps in research on propensity to trust. A great deal of research has been done on organizational trust, which is applicable since NCAA Division I athletic teams have many organizational attributes.

Similar to trust in a K-12 school, the academic support structure for student-athletes considers trust essential in a high-functioning institution. Academic advising, in general, "is integral to fulfilling the teaching and learning mission of higher education" (NACADA, 2006).Academic advisors provide course counseling and guide student-athletes into courses that meet major or graduation requirements, helping them create and follow a graduation plan. Advisors often act as the central touch point for college students who are learning to navigate the nuances of a campus. Advisors do not necessarily provide all support services for a student, but are often charged with the responsibility of directing students to proper support services. In the case of student-athletes, academic advisors must also follow strict NCAA continuing academic eligibility requirements when suggesting appropriate college coursemwor. Thus, the relationship of trust developed between the advisor and student is a fundamental compoment of the student's college experience because so much trust is placed in the instructions given by the advisor.

Learning specialists focus on teaching positive educational behaviors that lead to academic success: for example class attendance, proper note taking, positive interaction with professors, appropriate engagement in class, and a proper amount of study time devoted to each course, project, assignment, and exam. The learning specialist has a role similar to a K-12 teacher assistant: providing individual attention to the learning of a caseload of student-athletes. Tutors provide content-specific learning through instructing student-athletes one-on-one outside of class, conducting group reviews for exams, and adding depth to critical course content not offered by the professor. The institution provides these 
service to enhance, not replace, the experience in the classroom.

\subsection{Research Questions}

In order to determine the impact propensity to trust may have on NCAA Division I student-athletes' academic success, the authors examined demographic and educational attributes correlated with aggregated Propensity to Trust Scale (PTTS; Frazier et al., 2013) scores of student-athletes at a large private NCAA Division I institution. Specifically, the researchers considered (a) the demographic and educational factors associated with student-athletes' propensity to trust, (b) variability of propensity to trust among athletic teams, and (c) ways educational and demographic variables and propensity to trust predicted student-athletes academic achievement at the time of the study. With these considerations, this research explored the following questions:

1. What demographic factors are associated with student-athletes' propensity to trust?

2. What educational factors are associated with student-athletes' propensity to trust?

3. Does propensity to trust vary among athletic teams?

4. In what ways have do educational and demographic variables and propensity to trust predict student-athletes' current academic achievement at the time of the study?
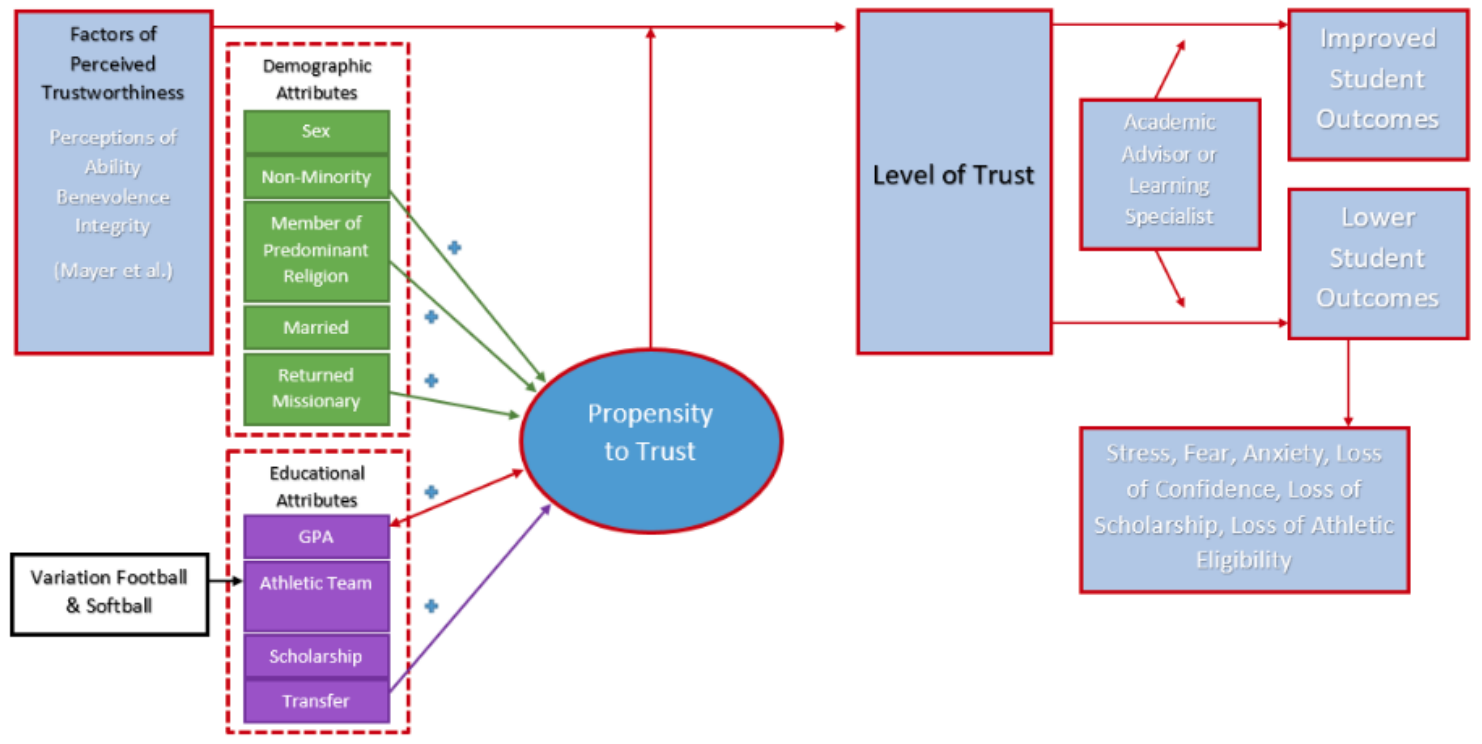

Figure1. Proposed model of study.

As portrayed in Figure 1, the researchers hypothesized that demographic and educational variables in the study would explain a variance in propensity to trust, thus moderating the strength of the relationship of trust to Mayer et al.'s (1995) factors of perceived trustworthiness: ability, benevolence, and integrity. Germane to the hypotheses in this study are the predictions that (a) "propensity contributes to the explanation of variance in trust if used as a more complete set of variables" (Mayer et al., 1995, p. 716) and (b) the trustor's propensity acts as a "stable within-party factor that will affect the likelihood the party will trust" (p.715). The higher level of trust will ultimately yield results that lead to improved academic outcomes for student-athletes.

\section{METHODS}

\subsection{Sampling}

The target population for this study was all NCAA Division I student-athletes at a large, private, religious university in the United States. The sampling frame included all student-athletes over the age of 18 in the institution's administrative database ( $\mathrm{N}=463)$. All 463 of these student-athletes were invited through email to participate in the study. Of the 463 possible participants, 221 returned surveys, representing a $47.7 \%$ response rate.

\subsection{Survery Instruments and Data Collection}

We used Frazier, Johnson, and Fainshmidt's (2013) Propensity to Trust Scale to measure studentathletes' propensity to trust. This instrument is derived from four items, measured on a 5-point Likerttype scale (from $1=$ strongly disagree to $5=$ strongly agree $)$. 
Impact of Propensity to Trust on Academic Success of Student-Athletes: Implications for Student-Athlete Academic Support in Higher Education

1. I usually trust people until they give me a reason not to trust them.

2. Trusting another person is not difficult for me.

3. My typical approach is to trust new acquaintances until they prove I should not trust them.

4. My tendency to trust others is high.

Frazier et al.'s scale, validated in their 2013 paper $(\alpha=0.89)$, is commonly used in research on trust. Results from our data provided further evidence of the reliability of the PTT construct $(\alpha=0.88)$, which signifies a high degree of internal consistency among these four items in measuring latent PTT. In addition, we collected data on participant demographics (gender, marital status, minority status, missionary service, religious affiliation etc.);educational factors (scholarship status, transfer student status, high school GPA, ACT score, university GPA, etc.); and athletic team affiliation to determine the relationship of these factors to propensity to trust. The author chose these variables based on practical experience, anticipating the possibility of demographic and educational PTT differences. In addition, these variables may allow practitioners the opportunity to examine better ways to support various groups. Tables 1 and 2 provide the demographic characteristics of the participants in the sample.

Table1. Demographic Characteristics of the Sample (Dichotomous Variables)

\begin{tabular}{|c|c|c|c|}
\hline & & $n$ & $\%$ \\
\hline \multirow{5}{*}{ Demographic characteristics } & Female & 117 & 53.0 \\
\hline & Member of university's sponsoring church & 183 & 82.8 \\
\hline & Married & 48 & 21.7 \\
\hline & Minority & 56 & 25.3 \\
\hline & Returned missionary & 79 & 35.7 \\
\hline \multirow{4}{*}{ Educational characteristics } & Scholarship & 131 & 59.2 \\
\hline & Non-scholarship & 90 & 40.7 \\
\hline & Transfer & 15 & 6.7 \\
\hline & Non-transfer & 206 & 93.2 \\
\hline \multirow{17}{*}{ Athletic teams } & Men's golf & 2 & 0.9 \\
\hline & Baseball & 5 & 2.2 \\
\hline & Men's football & 44 & 19.9 \\
\hline & Men's basketball & 4 & 1.8 \\
\hline & Men's swim & 11 & 4.9 \\
\hline & Men's tennis & 3 & 1.3 \\
\hline & Men's volleyball & 9 & 4.0 \\
\hline & Men's track & 26 & 11.7 \\
\hline & Women's softball & 8 & 3.6 \\
\hline & Women's basketball & 6 & 2.7 \\
\hline & Women's swim/dive & 17 & 7.6 \\
\hline & Women's golf & 6 & 2.7 \\
\hline & Women's soccer & 13 & 5.8 \\
\hline & Women's tennis & 7 & 3.1 \\
\hline & Women's track & 25 & 11.3 \\
\hline & Women's volleyball & 6 & 2.7 \\
\hline & Women's gymnastics & 28 & 12.6 \\
\hline
\end{tabular}

Table2.Demographic Characteristics of the Sample (Continuous Variables)

\begin{tabular}{|l|r|r|l|l|}
\hline & Mean & SD & Min & Max \\
\hline ACT & 24.29 & 4.31 & 16 & 34 \\
\hline Current GPA & 3.31 & .55 & 1.46 & 4 \\
\hline Age & 20.57 & 2.24 & 18 & 27 \\
\hline PTT & 14.72 & 3.59 & 6 & 20 \\
\hline
\end{tabular}

\subsection{Data Analysis}

To answer our research questions regarding the relationships between student-athletes' background characteristics, educational factors, propensity to trust, and academic achievement, we used various statistical models, including analysis of variance (ANOVA) and ordinary least squares (OLS) regression. We used ANOVA to compare PTT by athletic team. We tested for pair wise differences 
among teams using Fisher's Least Significant Differences (LSD) post-hoc test (Fisher, 1935), and we applied OLS regression to analyze the potential predictors of GPA and PTT for our student-athletes, controlling for other demographic and educational variables. Table 3 provides the group mean differences in PTT for the explanatory variables in our research questions: scholarship status, transfer status, minority status, religious affiliation, missionary experience, gender, and marital status.

\section{Results}

Results suggest that non-minority students (mean difference $=2.4$; Cohen's $d=.64$ ), students affiliated with the church sponsoring the university (mean difference $=2.8$; Cohens's $d=.79$ ), and students who had served a religious mission for this church (mean difference $=1.8$; Cohen's $d=.54$ ) had significantly higher propensity to trust than minority students, those not affiliated with the sponsoring church with a different religious affiliation, and those who had not served a religious mission.

Table3. Comparing Student-Athletes' PTT by Demographic, Academic, and Religious Characteristics

\begin{tabular}{|l|l|l|l|l|l|}
\hline Variable & Condition & $\mathrm{n}$ & Mean & SD & Mean Diff. \\
\hline \multirow{2}{*}{ Scholarship } & No scholarship & 90 & 15.1 & 3.5 & 0.7 \\
\cline { 2 - 6 } & Scholarship & 131 & 14.4 & 3.6 & \\
\hline \multirow{2}{*}{ Transfer } & Transfer student & 14 & 15.2 & 4.3 & 0.6 \\
\cline { 2 - 6 } & Not a transfer student & 207 & 14.6 & 3.5 & \\
\hline \multirow{2}{*}{ Minority } & Minority student & 56 & 12.9 & 4.0 & $-2.4^{* * * *}$ \\
\cline { 2 - 6 } & Non-minority student & 165 & 15.3 & 3.2 & \\
\hline \multirow{2}{*}{ Religious affiliation } & Shares university religious affiliation & 183 & 15.2 & 3.4 & $2.8^{* * *}$ \\
\cline { 2 - 6 } & Does not share university religious affiliation & 38 & 12.4 & 3.6 & \\
\hline \multirow{2}{*}{ Missionary service } & Has served a mission & 79 & 15.9 & 3.0 & $1.8^{* * * *}$ \\
\cline { 2 - 6 } & Did not serve a mission & 142 & 14.1 & 3.7 & \\
\hline \multirow{2}{*}{ Gender } & Male & 104 & 14.6 & 3.6 & -0.2 \\
\cline { 2 - 6 } & Female & 117 & 14.8 & 3.5 & \\
\hline \multirow{2}{*}{ Marital status } & Married & 48 & 14.6 & 3.4 & -0.1 \\
\cline { 2 - 6 } & Not married & 173 & 14.7 & 3.3 & \\
\hline
\end{tabular}

Note. $* * * \mathrm{p}<0.01, * * \mathrm{p}<0.05, * \mathrm{p}<0.1$

\subsection{Differences in Propensity to Trust by Athletic Team}

One of our research questions asked whether student-athletes' propensity to trust varied across the university's 17 athletic teams. The average PTT score across athletic teams was 14.7 . The teams with the highest mean PTT scores were men's basketball (16.7), women's soccer (15.7), women's swim (15.7), and men's tennis (15.7). The teams with the lowest mean PTT scores were women's softball (10.7), women's golf (13.2), and men's football (13.3). Results from a one-way ANOVA suggested significant differences in PTT across teams, $F_{(16,204)}=1.7, p=.046$. Results from Fisher's LSD posthoc test suggested that men's football and women's softball demonstrated significant differences in mean PTT scores from a number of other teams. Specifically, women's softball scored significantly lower than every team except men's football, women's golf, and women's tennis. Meanwhile, men's football had lower PTT than women's gymnastics, men's track, women's swim, women's soccer, and women's track. None of the other teams in the study demonstrated significant differences from each other.

\subsection{Predictors of Academic Achievement and Propensity to Trust}

Our primary research questions were concerned with investigating (a) the relationships of student background, academic success, and athletic team with propensity to trust, and (b) the extent to which these characteristics, including propensity to trust, predicted student academic achievement; we analyzed both using OLS regression. The first regression model (see Table 4) represented four variables that are significantly associated with students' propensity to trust: minority status, mission experience, transfer status, and GPA. Holding all other variables constant, minority students' PTT scores were 1.69 points $(0.47 \mathrm{SD})$ lower than those of non-minority students, former missionaries had higher PTT than those who had not been missionaries (mean difference $=1.79 ; 0.50 \mathrm{SD}$ ), and transfer 
Impact of Propensity to Trust on Academic Success of Student-Athletes: Implications for Student-Athlete Academic Support in Higher Education

students exhibited higher PTT than non-transfer students (mean difference $=3.58 ; 1.0 \mathrm{SD}$ ). A onepoint increase in student GPA was associated with a 1.39 (0.39 SD) increase in PTT. Overall, this set including demographic and academic characteristics and team affiliation accounted for $26 \%$ of the variation in student propensity to trust $\left(R^{2}=0.26\right)$.

The second regression model in Table 4 regressed student-athletes' grade point average on this same set of covariates plus student propensity to trust. This set of independent variables explained $46 \%$ of the observed variation in student GPA $\left(R^{2}=0.46\right)$. The strongest predictor of college GPA was shown to be high school GPA; for every 1 SD increase in a student's high school GPA, his college GPA increased $0.46 \mathrm{SD}(p<.001)$. Two variables also significantly predicted student college GPA: ACT score $(p=.01)$ and propensity to trust $(p=.009)$. A one SD increase in both ACT and PTT was associated with a $0.16 \mathrm{SD}$ increase in student GPA.

Table4. Predictors of Propensity to Trust and Grade Point Average, OLS

\begin{tabular}{|c|c|c|}
\hline & (1) & $(2)$ \\
\hline & Propensity to trust & Grade point average \\
\hline \multirow{2}{*}{ Constant } & 3.75 & .808 \\
\hline & $(4.84)$ & $(.638)$ \\
\hline \multirow[t]{2}{*}{ Age } & .231 & -.027 \\
\hline & $(.214)$ & $(.028)$ \\
\hline \multirow[t]{2}{*}{ High school GPA } & -.108 & $.676^{* * *}$ \\
\hline & $(.809)$ & $(.095)$ \\
\hline \multirow[t]{2}{*}{$\mathrm{ACT}$} & .039 & $.020^{* *}$ \\
\hline & $(.059)$ & $(.008)$ \\
\hline \multirow[t]{2}{*}{ Minority } & $-1.69^{* * * *}$ & -.091 \\
\hline & $(.577)$ & $(.078)$ \\
\hline \multirow[t]{2}{*}{ Religious affiliation } & $1.39^{*}$ & -.127 \\
\hline & $(.734)$ & $(.097)$ \\
\hline \multirow[t]{2}{*}{ Scholarship } & .146 & .025 \\
\hline & $(.484)$ & $(.064)$ \\
\hline \multirow[t]{2}{*}{ Mission } & $1.79^{* * *}$ & -.039 \\
\hline & $(.707)$ & $(.095)$ \\
\hline \multirow[t]{2}{*}{ Year in school } & -.321 & $\begin{array}{l}.052 \\
\end{array}$ \\
\hline & $(.312)$ & $(.041)$ \\
\hline \multirow[t]{2}{*}{ Married } & $-1.13^{*}$ & .076 \\
\hline & $(.648)$ & $(.086)$ \\
\hline \multirow[t]{2}{*}{ Non-native English speaker } & .783 & .063 \\
\hline & $(1.16)$ & $(.153)$ \\
\hline \multirow[t]{2}{*}{ Transfer student } & $3.58^{* * * *}$ & $-.306^{*}$ \\
\hline & $(1.16)$ & $(.156)$ \\
\hline \multirow[t]{2}{*}{ Gender } & .869 & .019 \\
\hline & $(.594)$ & $(.079)$ \\
\hline \multirow[t]{2}{*}{ Grade point average } & $1.39^{* * * *}$ & \\
\hline & $(.527)$ & \\
\hline \multirow[t]{2}{*}{ Propensity to trust } & & $.024^{* * * *}$ \\
\hline & & $(.009)$ \\
\hline Observations & 213 & 213 \\
\hline$R^{2}$ & 0.260 & 0.462 \\
\hline
\end{tabular}

Note. Standard errors in parentheses

$* * * p<0.01, * * p<0.05, * p<0.10$

\subsection{Discussion}

The purpose of this study was to examine the impact propensity to trustmighthave on NCAA Division I student-athletes' academic success. Limited research has been done in this area. This study 
attempts to help fill this gap by clarifying which variables may influence high or low propensity to trust (see Figure 2) among student-athletes.

Specifically, this research found that a number of student characteristics predicted a high propensity to trust: being of the ethnic-cultural majority, being affiliated with the predominant religion, having served a religious mission, and having transferrd from another institution. Students with higher grade point averages also demonstrated greater propensity to trust. Other characteristics did not predict a higher propensity to trust: sex, marital status, scholarship support, high school GPA, ACT score, native language, and year in school.

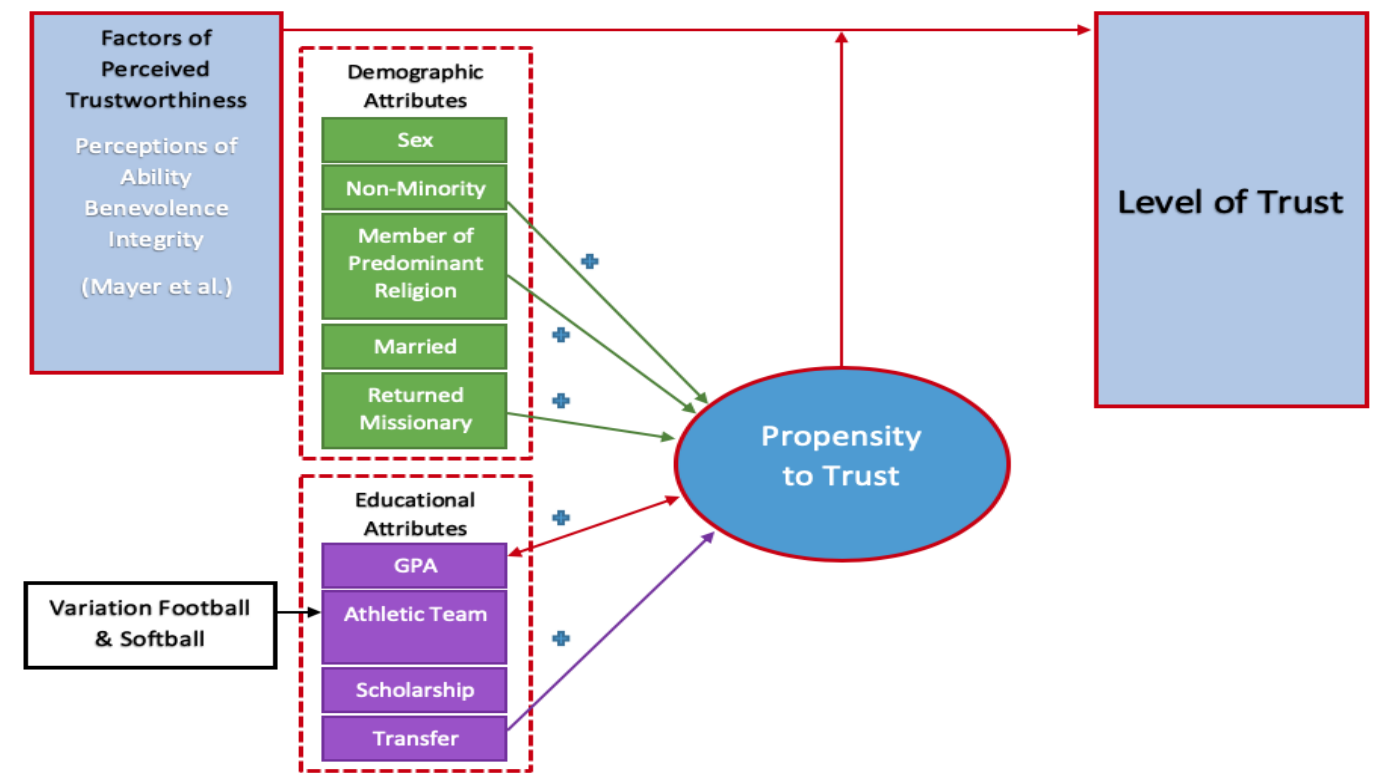

Figure2.Attributes found in the study to affect PTT

+ shows variables demonstrating higher PTT

Most of the 17 athletic teams studied did not vary significantly in members' propensity to trust, with the exceptions being the women's softball and men's football teams, which had lower average propensity to trust than a large share of the other athletic teams. Findings of the study also indicated that propensity to trust positively correlated with the GPA of student-athletes at the time of the research. Certainly additional study is needed to investigate the predictors of propensity to trust, their relationship with student academic performance. But understanding any differences in propensity to trust among NCAA Division I student-athletes will increase advisors' and learning specialists' ability to understand students' academic needs and provide support.

A few of the significant findings warrant further discussion, including the relationship between PTT and GPA, the significant difference in PTT between student-athletes who were and were not members of the predominant religion, and differences for student-athletes who had and had not served religious missions, along with the lack of relationship between gender and PTT.

\subsection{PTT and GPA}

The relationship between student-athletes' PTT and current GPA was the most significant finding of this research. Some of this positive relationship might be informed by the assertion of Rotter (1971) that individuals with a high propensity to trust are more likely to act in a trustworthy manner. Association between academic achievement, as measured by GPA, and PPT may demonstrate that high propensity to trust propels students to be more likely to attend class, take notes, study for exams, receive help from academic support, and generally behave in ways student-athletes are expected to behave.

Goddard, Tschannen-Moran, and Hoy (2001) claimed trusting relationships make an important contribution to students' academic achievement. They found that "after accounting for the effects of student characteristics . . . Trust is a positive predictor of the variance in student achievement among schools" (p. 14). Though Goddard et al.'s (2001) study population was elementary students in an 
urban setting, one can presume that university student-athletes who have a high propensity to trust will feel less vulnerable than student-athletes with low propensity to trust, when it comes to trusting learning specialists, coaches, teammates, and support staff. As a result student-athletes with high propensity to trust will spend less time and energy trying to protect themselves and will be more likely to ask questions, collaborate, and generally feel efficacious, believing they can achieve rather than be vulnerable to failure.

However, we recognize that our results are only co relational conclusions. Thus the direction of any causal relationship between PTT and GPA could in reality be reversed: Individuals might be more likely to trust an organization that has facilitated their academic success, while students struggling academically might be more skeptical of whether the organization prioritizes their academic progress. Such a reality might also intersect a factor such as minority status: Minority students who perceive institutions of higher education as having been less concerned with the success of ethnic and social minorities may beless inclined to (a) attempt to succeed in such environments, and (b) freely demonstrate trust. In this study, minority students scored 1.69 points $(0.47 \mathrm{SD})$ lower than nonminority students in propensity to trust.

Another possible explanation for the relationship between propensity to trust and current GPA is based on research that indicates a link between trust and a variety of positive work attitudes, such as job satisfaction, organizational commitment, work behaviors, job performance, and citizenship behavior (e.g., Aryee, Bud war, \& Chen, 2002; Watson \&Papamarcos, 2002). Many student-athletes see themselves first as an athlete and second as a student: an athlete-student. When viewed this way, school achievements, such as GPA, become more closely related to those expected in organizational commitment. Continuing eligibility is highly prescribed by the NCAA, and the right to compete in a sport may be more likely viewed by NCAA Division I student-athletes as a condition of employment. When viewed through the "athlete-student" lens, the practical application of current GPA becomes more of an organizational trust variable than an educational one.

\subsection{PTT and Membership and Missionary Service in the Predominant Religion}

The finding of higher PTT for members of the university's sponsoring church had been anticipated, as the church emphasizes the value of learning and teaches respect for those who teach and facilitate faith. The student-athletes involved in the study who had served a mission for this church were all members of the church at the time, so the first of these findings would presuppose the second.

Studies performed by Mayer et al. (1995) found intention to trust was influenced by perceived characteristics of the trustee and predisposition of the trust or. Specifically, the ability, benevolence, and integrity the trust or perceives in the trustee predictsthetrustor's intention to trust. Since the predominant religion of the university's students is also predominant among its faculty and staff, prior experiences of those students might have predisposed them to trust those coaches, academic support staff, and teammates who shared their religious beliefs and practices; thus institution-based trust might have been a result of participants' earlier experiences. Trust among church members is emphasized by the predominant religion; therefore, those who were members of the religion likely had had personal experiences of perceived ability, benevolence, and integrity with trustees in comparable relationships (Mayer et al., 1995), allowing the trustors to more readily recognize trust patterns or characteristics. Thus participation in the predominant religion might have increased trust based on guarantees and recommendations from third parties (Zucker, 1986).

An individual who had recently spent 18 to 24 months serving a church mission might have had his or her propensity to trust further enhanced by strong trust-relevant situations encountered during the mission. During this service, missionaries interact continually with strangers, and those who serve in a foreign country have the additional vulnerability of speaking new languages and living with unfamiliar cultures and customs. The trust they must place in their leaders and peers is based in firm religious beliefs and values, thus cementing perceptions and predispositions for trust. This experience, which is true of many missionaries, is consistent with the above-referenced position of Mayer et al. (1995) that trust is influenced by perceived characteristics of the trustee and predisposition of the trust or. Former missionaries had the highest mean PTT (15.91) among all studied groups, including student-athletes who were non-minority (15.32) and members of the affiiatedchurch (15.20).

Overall, the above findings of this study have been consistent with work on how trust development differs between in-groups and out-groups. Leader-member exchange (LMX) theory enlightens how 
in-group/out-group differences impact various components leading to trusting behaviors (Anand, $\mathrm{Hu}$, Liden, \&Vidyarthi, 2011; Graen\&Uhl-Bien, 1995). The findings of this study support earlier empirical work viewed through the LMX framework indicating that in-groups initially perceive more favorably their leaders' benevolence, openness, and capacity, leading to better relational outcomes for in-group members (Harris, Wheeler, \&Kacmar, 2009; Ilies, Nahrgang, \&Morgeson, 2007).

\subsection{PTT and Gender}

Positive association between gender (In this study, gender is defined as biological sex determined at birth) and propensity to trust and gender was an unexpected finding, considering the vulnerability of females to be harmed (physically or mentally) or to feel threatened (Buchan, Croson, \&Solnick, 2008; Maccoby \& Jacklin, 1974) on college campuses. However, the popular expectation that females would be less likely to trust than males may not have been applicable to this group, as women who are competing at the NCAA Division I level have likely overcome gender-based stereotypes. As they participate in athletics, these individuals may have more trust-building experiences within an intra group than students who are not athletes; thus they have already made themselves vulnerable to and overcome stereotypes. As with those who are members of the majority religion, propensity to trust correlates with intention to trust when information about trustworthiness is clear (Gill et al., 2005).The information available to most male and female athletes should be equally clear.

\subsection{Practical Implications}

This study has multiple practical implications. Various target groups of individuals are considered.

Implications for NCAA Division 1 athletics. First, this research validates the complexity of NCAA Division I college athletics and the NCAA's ability to maintain integrity in referring to its participants as student-athletes. Many institutions, including the institution where this study was conducted, use athletic skill as a criterion for admission consideration. In such cases, student-athletes may have lower academic scores and in some cases may not be fully prepared for the rigor of a college education. The NCAA understands this and has encouraged institutions to provide support systems to assist student-athletes. Each student-athlete is an individual who requires individual supportparticularly academic support. Understanding how propensity to trust influences different individuals and groups may lead to more effective academic support as those serving in the programs find ways to increase trust among those who may hesitate to seek the help that they need.

Implications for university academic advisors. Academic advising is "a series of intentional interactions with a curriculum, a pedagogy, and a set of student learning outcomes" and is be tailored to student's "individual characteristics, values, and motivations" (NACADA, 2006). Individuals who provide academic support or advising for student-athletes would benefit from working to build trust by finding ways to show benevolence, reliability, competence, openness and honesty, affirmed by Hoy \&Tschannen-Moran (1999) as five facets of trust. Academic advisors would benefit from Lynne Zucker's (1986) definition of trustas "a set of expectations shared by all those involved in an exchange," including both "broad social rules" and "legitimately activated processes" (p. 54). These advisors can be more effective if they understand and facilitate this exchange. Additionally, if academic advisors understand student-athletes 'propensity to trust, motivation to trust (Williams, 2001), and intention to trust (Gill et al., 2005), they are in a better position to influence studentathletes' motivation to trust them in their supportive roles. If they can influence the student-athletes' "desire to view [them] as trustworthy enough to be relied on" (Williams, 2001, p. 387), studentathletes are more likely to realize positive academic outcomes.

Building interdependent trust between academic advisors and student-athletes helps to reduce uncertainty (Holmes \& Rempel, 1989; Luhmann, 1979) and raise student-athletes' trust. The academic advisor can also reduce uncertainty by setting high academic expectations. Higher expectations result in higher levels of trustworthiness, influencing not only the current well-being of the student-athlete but future academic potential as well (Tschannen- Moran \& Hoy, 2000).

Implications for institutional environment. Understanding how to develop trust with studentathletes who have low propensity to trust will benefit an NCAA Division I institution in balancing and blending competitive and cooperative environments. Coaches, and often college athletic administrators, are charged with winning games, and the academic support personnel are expected to provide student-athletes with academic support so that they are eligible to play. In 2017 when this study was conducted, football had the lowest mean PTT score of all men's teams. In that particular 
season the football team had had four wins compared to nine losses. This was the first losing season the team had experienced in 13 years. This study did not focus on the relationship between competition and propensity to trust; however, further studies may examine the relationship using these data.

Whereas coaches and administrators work consistently in a competitive environment, academic support staff work in a cooperative environment. While athletic competition produces winners and losers, academic success maintains steady effort toward an ultimate goal all student-athletes can achieve: graduation. Leaders who can garner a sense of trust from their people are more likely to achieve better results regardless of whether the environment is cooperative or competitive. Thus, higher propensity to trust can contribute in both settings.

Finally, this study can be used to understand trends that occur in other educational environments. Though it does appear student-athletes have a unique set of competing interests, such as academics and their sport, other university students face similar competing interests with academics and work, academics and social experiences, or academics and family responsibilities. Application of this research goes considerably beyond NCAA Division I student-athletes.

\subsection{Limitations}

The most obvious limitation with this study was that it was conducted at one large private university owned and administered by an international church. As a result, a high majority of the subjects considered in this study belonged to the religion affiliated with the university. Few institutions of higher learning have such a large proportion of students sharing the same group affiliation. This common student-athlete /institution affilitationmay bias some of the results. Particularly, unknown factors might have affected participants' answers to the PTTS questions developed by Frazier et al. (2013).A more traditional institution might be used for future studies regarding propensity to trust and NCAA Division I student-athletes.

Finally, another limitation may be that a single assessment of propensity to trust is assumed in this study to have been stable over a period of time. An individual's propensity to trust may change; thus, a longitudinal study of propensity to trust performed on the same subjects may provide additional insights.

\section{CONCLUSION}

Discovering methods for academic advisors to help support NCAA Division I student-athletes is increasingly challenging. The difficulties in balancing NCAA competitive structures and practices and NCAA requirements for academic progress will only prove more challenging in the future as more emphasis and school revenue are placed on winning in athletics as opposed to success in academics. Results from this study provide evidence that coaches, administrators, and, most importantly, academic advisors can take a holistic approach to supporting student-athletes by building on students' initial propensity to trust, thus helping NCAA-sponsored programs maintain a successful relationship between athletic competition and academic achievement.

Overall performance of most NCAA Division I athletic programs, including those at the institution where this study was performed, can be defined by three major outcomes:(a) competitive outcomes such as winning games, matches, rivalries, and championships, (b)perceived character or citizenship of its student-athletes, and (c)academic achievements (i.e., GPA and graduation rates) of the studentathletes. Since this study does not examine wins and losses or overall citizenship, the results apply most specifically to academic advisors charged with helping student-athletes achieve academic success. Like other institutions affiliated with the NCAA, the university where this research occurred provides educational opportunities for students who would not otherwise have been qualified to be admitted. In this regard, understanding student-athletes 'propensity to trust may provide insights that will enhance the vital role college athletics plays in providing an education to diversely prepared populations.

\section{REFERENCES}

[1] Anand, S., Hu, J., Liden, R. C., \& Vidyarthi, P. R. (2011). Leader-member exchange: Recent research findings and prospects for the future. In A. Bryman. D. Collinson, K. Grint, G. Jackson, \& B. Uhl-Bien (Eds.), The SAGE handbook of leadership (pp. 211-325). London, UK: SAGE.

[2] Aryee, S., Budhwar, P. S., \& Chen, Z. X. (2002). Organizational justice, trust foci, and work outcomes: Test of a mediated social exchange model. Journal of Organizational Behavior, 23(3), 267-285. 
[3] Brown, S. D.,Hallam, P. R.,Hite, S. J., \& Hite, J. M. (2016). The Impact of Various Demographic and Educational Attributes on International Students' Propensity to Trust School Officials. Education and Society, 34(2), 49-68.

[4] Buchan, N., Croson, R., \&Solnick, S.(2008).Trust and gender: An examination of behavior and beliefs in the investment game. Journal of Economic Behavior and Organization, 68(3),466-476.

[5] Burke, C., Sims, D. E., Lazzara, E., \& Salas, E. (2007). Trust in leadership: A multi-level review and integration. The Leadership Quarterly, 18(6), 606-632.

[6] Conlon, E. J., \& Mayer, R. C. (1994). The effect of trust on principal-agent dyads: An empirical investigation of stewardship and agency. Paper presented at the annual meeting of the Academy of Management, Dallas, TX.

[7] Costa, A. C., Roe, R. A., \& Taillieu, T.C.B. (2001). Trust implications for performance and effectiveness. European Journal of Work \& Organizational Psychology, 10(3), 225-244.

[8] Deutsch, M. (1958). Trust and suspicion. Journal of Conflict Resolution, 2(4), 265-279.

[9] Dirks, K., \&Ferrin, D. (2002). Trust in leadership: Meta-analytic findings and implications for research and practice. Journal of Applied Psychology, 87(4), 611-628.

[10] Fisher, R.A.(1935).Design of Experiments.London, UK: Oliver \& Boyd.

[11] Frazier, M., Johnson, P., \&Fainshmidt, F. (2013). Development and validation of a propensity to trust scale. Journal of Trust Research, 3(2), 76-97.

[12] Gill, H., Boies, K., Finegan, J., \& McNally, J. (2005). Antecedents of trust: Establishing a boundary condition for the relation between propensity to trust and intention to trust. Journal of Business and Psychology, 19(3), 287-302.

[13] Goddard, R.D., Tschannen-Moran, M., \&Hoy, W.K.(2001).A multilevel examination of the distribution and effects of teacher trust in students and parents in urban elementary schools. The Elementary School Journal, 102(1), 3-17.

[14] Graen, G. B., \&Uhl-Bien, M. (1995). Relationship-based approach to leadership: Development of leadermember exchange (LMX) theory over 25 years: Applying a multi-level, multi-domain perspective. Leadership Quarterly, 6(2), 219-247.

[15] Hardin, R. (1993). The street-level epistemology of trust. Politics and Society, 21(4), 505-529.

[16] Harris, K. J., Wheeler, A. R., \&Kacmar, K. M. (2009). Leader-member exchange and empowerment: Direct and interactive effects on job satisfaction, turnover intentions, and performance. Leadership Quarterly, 20, 371-382.

[17] Holmes, J. G., \& Rempel, J. K. (1989). Trust in close relationships. In C.Hendrick (Ed.), Close relationships (pp. 187-220).Newbury Park, CA: Sage Publications.

[18] Hoy, W., \& Tschannen-Moran, M. (1999). Five faces of trust: An empirical confirmation in urban elementary schools. Journal of School Leadership, 9(3), 184-208.

[19] Ilies, Nahrgang, \&Morgson (2007). Leader-member exchange and citizenship behaviors: A meta-analysis. Journal of Applied Psychology, 92(1), 269-277.

[20] Kramer, R. (1999). Trust and distrust in organizations: Emerging perspectives, enduring questions. Annual Review of Psychology, 50(1), 569-598.

[21] Luhmann, N. (1979). Trust and power. New York, NY: Wiley.

[22] Maccoby, E., \& Jacklin, C.(1974).The psychology of sex differences. Redwood City, CA: Stanford University Press.

[23] Mayer, R., Davis, J. H., \&Schoorman, F. (1995). An integrative model of organizational trust. Academy of Management Review, 20(3), 709-734.

[24] McKnight, D., Cummings, L., \&Chervany, N. (1998). Initial trust formation in new organizational relationships. Academy of Management Review, 23(3), 473-490.

[25] Mishra, A. (1996). Organizational response to crisis: The centrality of trust. In R. M. Kramer \& T. R. Tyler (Eds.), Trust in organizations: Frontiers of theory and research (pp. 261-287). Thousand Oaks, CA: Sage Publications.

[26] NACADA: The Global Community for Academic Advising. (2006). NACADA concept of academic advising. Retrieved from https://www.nacada.ksu.edu/Resources/Pillars/Concept.aspx

[27] NCAA.org. (n.d.) Graduation rates. Retrieved from http://www.ncaa.org/about/resources/research/grad uation-rates

[28] Rosenberg, M., Suchman, E., \& Goldsen, R. (1957). Occupations and values. Glencoe, IL: Free Press. 
Impact of Propensity to Trust on Academic Success of Student-Athletes: Implications for Student-Athlete Academic Support in Higher Education

[29] Rotter, J. B. (1967). A new scale for the measurement of interpersonal trust. Journal of Personality, 35(4), $651-665$.

[30] Rotter, J. B. (1971). Generalized expectancies for interpersonal trust. American Psychologist, 26(5), 443452.

[31] Rousseau, D., Sitkin, S., Burt, R., \&Camerer, C. (1998). Not so different after all: A cross-discipline view of trust. The Academy of Management Review, 23(3), 393-404.

[32] Serva, M., Fuller, M., \& Mayer, R. (2005). The reciprocal nature of trust: A longitudinal study of interacting teams. Journal of Organizational Behavior, 26(6), 625-648.

[33] Sitkin, S., \& Roth, N. (1993). Explaining the limited effectiveness of legalistic "remedies" for trust/ distrust. Organization Science, 4(3), 367-392.

[34] Tschannen-Moran, M., \& Hoy, W. (2000). A multidisciplinary analysis of the nature, meaning, and measurement of trust. Review of Educational Research, 70(4), 547-593.

[35] Wageman, R. (1995). Interdependence and group effectiveness. Administrative Science Quarterly, 40(1), $145-180$.

[36] Watson, G. W., \&Papamarcos, S. D. (2002). Social capital and organizational commitment. Journal of Business and Psychology, 16(4), 537-552.

[37] Williams, M. (2001). In whom we trust: Group membership as an affective context for trust development. Academy of Management Review, 26(3), 377-396.

[38] Zucker, L. (1986). The production of trust: Institutional sources of economic structure, 1840-1920. In B. M. Staw\& L. L. Cummings (Eds.), Research in organization behavior (pp. 53-111). Greenwich, CT: JAI Press.

\section{AUTHORS' BIOGRAPHY}

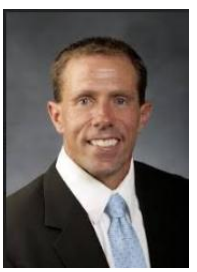

Trevor Wilson, is an Associate Dean of Students at Brigham Young University. He oversees academic and other support services for over 630 NCAA student-athletes. Previously, he was a high school and junior principal in the Ogden School District in Utah. He received a Doctorate Degree in Educational Leadership and Foundations from Brigham Young University, a Masters in Teaching from Willamette University, and a Bachelor of Science Degree from Brigham Young University-Hawaii. He has been an educator at the elementary, middle, and high school level and has also been an instructor at two postsecondary institutions. He and his wife Karri are the parents of three children and have nine grandchildren.

Pamela R. Hallam, is an Associate Professor and Chair of the Educational Leadership and Foundations Department at Brigham Young University. She has taught Instructional Leadership, Collaborative Leadership for Change, and Human Resource Management. She began her career as a high school teacher, before becoming a middle school principal, and then moving into the district office as the director of curriculum and technology. Her areas of academic interest include the role of trust in educational leadership and schools, professional learning communities, and collective efficacy, using qualitative methods.

Donald Baum, is an Assistant Professor of Education Policy at Brigham Young University. He teaches courses in international development, education policy, and policy analysis. His research focuses on the involvement of the non-state sector in education, as well as the policy and provision of early childhood education in the Global South.

Michael Owens, is an associate professor in the McKay School of Education's Educational Leadership and Foundations Department at Brigham Young University. He does research in educational leadership, professional development, evidence-informed decision making for continuous school improvement, multicultural education, and qualitative research methods. His academic interests include family and community engagement in schools, leader/followership, and continuous school improvement.

Citation: Dr. Trevor Wilson, et.al. "Impact of Propensity to Trust on Academic Success of Student-Athletes: Implications for Student-Athlete Academic Support in Higher Education" International Journal of Humanities Social Sciences and Education (IJHSSE), vol 7, no. 9, 2020, pp. 01-13. doi: https://doi.org/10.20431/23490381.0709001 .

Copyright: (1) 2020 Authors. This is an open-access article distributed under the terms of the Creative Commons Attribution License, which permits unrestricted use, distribution, and reproduction in any medium, provided the original author and source are credited. 